\title{
NEAR INFRARED SPECTROSCOPY FOR SEPARATION OF TAUARI WOOD IN BRAZILIAN AMAZON NATIVE FOREST
}

\author{
Santos JX ${ }^{1, *}$, Vieira $\mathrm{HC}^{1, *}$, Silva $\mathbf{E L}^{1}$, Muñiz GIB ${ }^{1}$, Soffiatti $\mathbf{P}^{2} \&$ Nisgoski $\mathbf{S}^{1}$ \\ ${ }^{1}$ Federal University of Paraná - UFPR, Department of Forest Engineering and Technology, Av. Prefeito Lothario Meissner - \\ Jardim Botânico, CEP: 80210-170, Curitiba, PR, Brazil \\ ${ }^{2}$ Federal University of Paraná - UFPR, Department of Botany, Jardim das Américas, 540, CEP:81531-990, Curitiba, PR, \\ Brazil
}

*joilan87xipaya@gmail.com

Submitted March 2019; accepted January 2020

\begin{abstract}
This work aimed to characterise different wood species known as tauari using the near infrared spectroscopy (NIR) as a support tool for identification. The spectra were obtained in a Tensor 37 spectrometer in the range of 4000-10000 $\mathrm{cm}^{-1}$, using 35 samples of solid wood from four different species with 21 different origins. Specimens measuring 2.5 centimeters long were extracted from each sample. The spectra were obtained on all faces of the samples and the analysis was performed in three different situations: i) sample mean, ii) only cross-sectional spectra and iii) only longitudinal (tangential and radial) spectra. The classification methods tested were linear discriminant analysis combined with principal component analysis (PCA-LDA). The best pretreatment was the second derivative, highlighting Couratari guianensis species with accuracy ranging from 55.6 to $61.1 \%$. The LDA classification, based on information from the NIR spectra, showed greater discriminatory potential for the species. However, due to the complexity of the separation of the tauari wood, the use of near-infrared (NIR) spectroscopy together with the anatomical identification is suggested, for confirmation of the species.
\end{abstract}

Keywords: Couratari spp., spectroscopy, spectral curves, Embrapa, Walter A. Egler collection

\section{INTRODUCTION}

The Brazilian Amazon has many tropical arboreal species that are attractive to the wood industry. These are often exploited illegally, contributing to the increase in deforestation index (Soares et al. 2017). The Amazon biome is important in this scenario because it represents $49.3 \%$ of Brazilian territory, with 13,375 catalogued species, of which 2,046 (15.4\%) are endemic to the country (Forzza et al. 2012, SFB 2013). Many species that produce wood of commercial value are similar even at the microscopic level (Soares et al. 2017).

In general, for forest species identification, reproductive and vegetative material is used, but for wood-producing species, characterisation based on anatomical characteristics is necessary, which is time consuming and needs specialists to obtain adequate results. So, new nondestructive techniques must be tested and refined to obtain more agility, practicality and precision in Amazon wood identification. One possibility is nearinfrared (NIR) spectroscopy, which is being successfully applied as a nondestructive method in the wood industry, with satisfactory quality analysis. In the past few years portable equipment has become available (Pastore et al. 2011, Bergo et al. 2016).

The NIR analysis of material with high moisture content, such as wood, is normally associated with statistical procedures that help identification and classification of the traits of interest, together with chemometrics, which involves mathematical procedures to derive significant chemical information from samples with high complexity, allowing the extraction of relevant data from the analysed material (Tsuchikawa \& Kobori 2015).

The NIR, in combination with multivariate analyses, carry information from various functional groups such as cellulose, hemicellulose, lignin and wood extractives present in wood (Tsuchikawa 2007). The NIR spectrum is a complex material consisting of a set of bands formed by the overlap of various vibrational transitions in the region of overtones and band combinations, which requires the establishment of a mathematical model that relates the obtained 
spectra with one or more properties of interest, either quantitatively or qualitatively, depending on the objective or chemometric method employed, of a sample under routine analysis (Pasquini 2003).

This technique enables measurements of light and sample interaction, which is the result of chemical vibration from constituents, and one reading can be performed in 90 seconds on average (Magalhães et al. 2005). Wood processing industries need fast methods, such as NIR analysis, that also enable more reliable species identification and classification (Yang \& Evans 2003). Many species with visually similar characteristics are present in commerce and can be distinguished by NIR analysis, such as Carapa guianensis, Cedrela odorata and Micropholis melinoniana (Pastore et al. 2011).

In the tropical wood trade, the group known as tauari comes from distinct tree species of the Lecythidaceae family, with similar characteristics (ITTO 2005). The trees have medium to high stature and are frequently found in the upper strata of lowland forests (Souza \& Lorenzi 2005). Its wood is moderately easy to cut and has good finish. It is widely used in civil construction, with demand in the national and international markets (Bernal et al. 2011, Paula \& Costa 2011). One problem is the difficulty of species discrimination. This is aggravated by the use of diverse vernacular names, making it hard to identify the species (Martins et al. 2003).

Thus, based on the importance of the tauari group and the difficulties of its identification, this study analysed wood samples from different species with NIR spectroscopy as a tool to support wood distinction.

\section{MATERIALS AND METHODS}

The study evaluated 36 wood samples known popularly as tauari, of four distinct species. The samples consisted of 18 specimens from scientific collections: nine from the Walter A. Egler Collection of Emilio Goeldi Paraense Museum (six Couratari guianensis, two C. stellata and one C. oblongifolia), and nine from Embrapa Amazônia Oriental, Pará state (four Couratari guianensis, two C. stellata, two C. oblongifolia and one C. multiflora) (Table 1). The materials are registered at the Conselho de Gestão do Patrimônio Genético (CGEN/SISGEN) as ADE10D5.

Table 1 Samples of tauari wood from Walter A. Egler Collection of Emilio Goeldi Paraense Museum and Embrapa Amazônia Oriental

\begin{tabular}{lll}
\hline Species & Registration & Origin of sample \\
\hline Couratari stellata & 2532-MGW & Suriname \\
Couratari stellata & 4468-MGW & Roraima \\
Couratari oblongifolia & 5399-MGW & Monte do Jari-PA \\
Couratari guianensis & 3437-MGW & Tucuruí-PA \\
Couratari guianensis & 5648 -MGW & Rio Sororo-PA \\
Couratari guianensis & 6348-MGW & Roraima \\
Couratari guianensis & 1981-MGW & Suriname \\
Couratari guianensis & 2462-MGW & Suriname \\
Couratari guianensis & 2907-MGW & Amapá-AP \\
Couratari stellata & 1790-IAN & Santarém-PA \\
Couratari stellata & 1792-IAN & Santarém-PA \\
Couratari guianensis & 6734 -IAN & Rio Juruá-PA \\
Couratari guianensis & 7812-IAN & Vila Santa Izabel-PA \\
Couratari guianensis & 7534-IAN & Novo repartimento-PA \\
Couratari guianensis & 1718-IAN & Santarém-PA \\
Couratari oblongifolia & 6752-IAN & Paragominas-PA \\
Couratari oblongifolia & 1774-IAN & Santarém-PA \\
Couratari multiflora & 1767-IAN & Rio Amazonas \\
\hline
\end{tabular}

MGW = Walter A. Egler Collection, Emílio Goeldi Paraense Museum, IAN = Embrapa Amazônia Oriental 
For complementation, 18 samples with dimensions of $50 \times 20 \times 5 \mathrm{~cm}$ (length, width and thickness) were collected randomly from 15 sawmills in 10 municipalities in Pará. Species identification was carried out in the Wood Anatomy and Quality Laboratory (LANAQM) at Federal University of Paraná (UFPR), Paraná state, Brazil. The sampling of the individuals in this research covered all the radial trunk variation, so there was no separation between heartwood and sapwood.

A microscopic characterisation was based on standards from the International Association of Wood Anatomists (IAWA 1989), and macroscopic was based on INTKEY interactive key of general and macroscopic characteristics of commercial woods from Brazil (Coradin et al. 2011). After anatomic characterisation, 18 samples were identified as from the Lecythidaceae family, composed of four species: six Couratari stellata, seven C. oblongifolia, four C. guianensis and one Eschweilera sp. (Table 2).

The NIR spectra were collected using a Tensor 37 , equipped with an integrating sphere and operating in reflectance mode, in a spectral range of 4000-10000 $\mathrm{cm}^{-1}$, with resolution of $4 \mathrm{~cm}^{-1}$ and 64 scans. Spectra were obtained from all surfaces of 35 samples and divided into transversal and longitudinal (radial and tangential) sections.
Six spectra were collected from each surface, 18 spectra per sample for a total of 630 spectra from all the tauari species. Materials were stored at controlled atmosphere with temperature of 25 $\pm 2{ }^{\circ} \mathrm{C}$ and relative humidity of $60 \pm 2 \%$.

The analysis and model construction were carried out based on data from the Walter A. Egler Collection and Embrapa Amazônia Oriental. External classification and identification were carried out with samples collected from sawmills in Pará. Data analysis was performed with Unscrambler X (version 10.1) in original form (raw data) and with second derivative values from Savitzky-Golay smoothing ( polynomial order $=2$, smoothing points $=15$ ).

The influence of the wood section from which the spectra were collected for species discrimination was also evaluated: i) mean value of sample, ii) mean value only of transversal surface of samples and iii) mean value only of longitudinal surface (radial and/or tangential) of samples.

The classification method applied was linear discriminant analysis (LDA) based on principal component analysis scores (PCA-LDA). The PCA was performed based on the Nonlinear Iterative Partial Least Squares (NIPALS) algorithm with mean centered data and cross validation. In model construction, some divergence was

Table 2 Samples collected in sawmills in Pará state and identified based on macro and microscopic characteristics of wood, by municipality

\begin{tabular}{llc}
\hline Municipality (origin) & Species & Number of samples identified \\
\hline Altamira & Couratari stellata & 1 \\
& Couratari oblongifolia & 2 \\
Eschweilera sp. & 1 \\
Uruará & Couratari oblongifolia & 1 \\
Novo Progresso & Couratari stellata & 3 \\
Goianésia & Couratari gtellata & 1 \\
Maracajá & Couratari guianensis & 1 \\
Paragominas & Couratari guianensis & 1 \\
Anapú & Couratari guianensis & 1 \\
Tailândia & Couratari stellata & 1 \\
Pacajá & Couratari oblongifolia & 1 \\
Breu Branco & Couratari oblongifolia & 1 \\
\hline Total & Couratari oblongifolia & 1 \\
\hline & Couratari oblongifolia & 1 \\
\hline
\end{tabular}


observed between samples from the Walter A. Egler Collection and Embrapa Amazônia Oriental. Thus, only data from the Embrapa samples were applied for external classification because the region where the material was collected was nearest to the sawmills.

\section{RESULTS AND DISCUSSION}

Mean NIR spectra of species collected from sawmills in Pará, spectral range of 4000-10000 $\mathrm{cm}^{-1}$, showed similarity and different intensity of absorbance (Figure 1). The species C. stellata, C. oblongifolia and Eschweilera sp. were more similar, and C. guianensis showed some divergence in baseline, principally in the region $5020-5473 \mathrm{~cm}^{-1}$. Li et al. (2019), studying a new pretreatment methods for Vis-NIR calibration modeling of air-dry density of Ulmus pumila wood, observed that the density and the spectrum vary according to the transformation method. Literature shows the influence of water in the region of 5051 $\mathrm{cm}^{-1}$ and bands from $5150-5220 \mathrm{~cm}^{-1}$, presence of hemicelluloses at $5236 \mathrm{~cm}^{-1}$ and $5245 \mathrm{~cm}^{-1}$, and also semi-crystalline or crystalline region of cellulose at $5464 \mathrm{~cm}^{-1}$ (Schwanninger et al. 2011).

To verify grouping formation, PCA was performed with mean second-derivative spectra of species by origin (Figure 2), i.e., with mean data for each sample collected from different municipalities of Pará. The second derivative was used as the best pretreatment because the main objective of this analysis was to make the dataset more homogeneous, in order to reduce the sources of non-informative variations and consequently improve the signal/noise ratio, making future matrices more conditioned to modeling (Rinnan et al. 2009, Souza and Poppi 2012).

In general, visual similarity of species and origin was observed. Some divergence occurred principally for C. guianensis, for which it was observed that the species had more influence on the grouping than the origin. The use of second derivative data for wood discrimination with adequate results has been reported for timber of various origins, as well as pine species and species named angelim, in Brazil (Sandak et al. 2011, Zhang et al. 2014, Horikawa et al. 2015, Hwang et al. 2016, Muñiz et al. 2016).

Two principal components explained $92 \%$ of the total variation of NIR with the second derivative data. All species from Altamira were similarly close. All C. stellata from Uruará were grouped, and C. stellata from Novo Progresso was grouped with C. oblongifolia from Uruará. Samples from C. guianensis collected in Goianésia, Maracajá and Paragominas were grouped. Samples from Anapú, C. stellata and C. oblongifolia were also grouped, and samples of $C$. oblongifolia obtained from Anapú, Breu Branco, Pacajá and Tailândia were in the same quadrant. The results were probably related to edaphoclimatic and forest conditions. Also, materials were collected from sawmills without identification of its origin, which poses a problem since trees are often felled in one place and the logs are taken to sawmills in different municipalities.

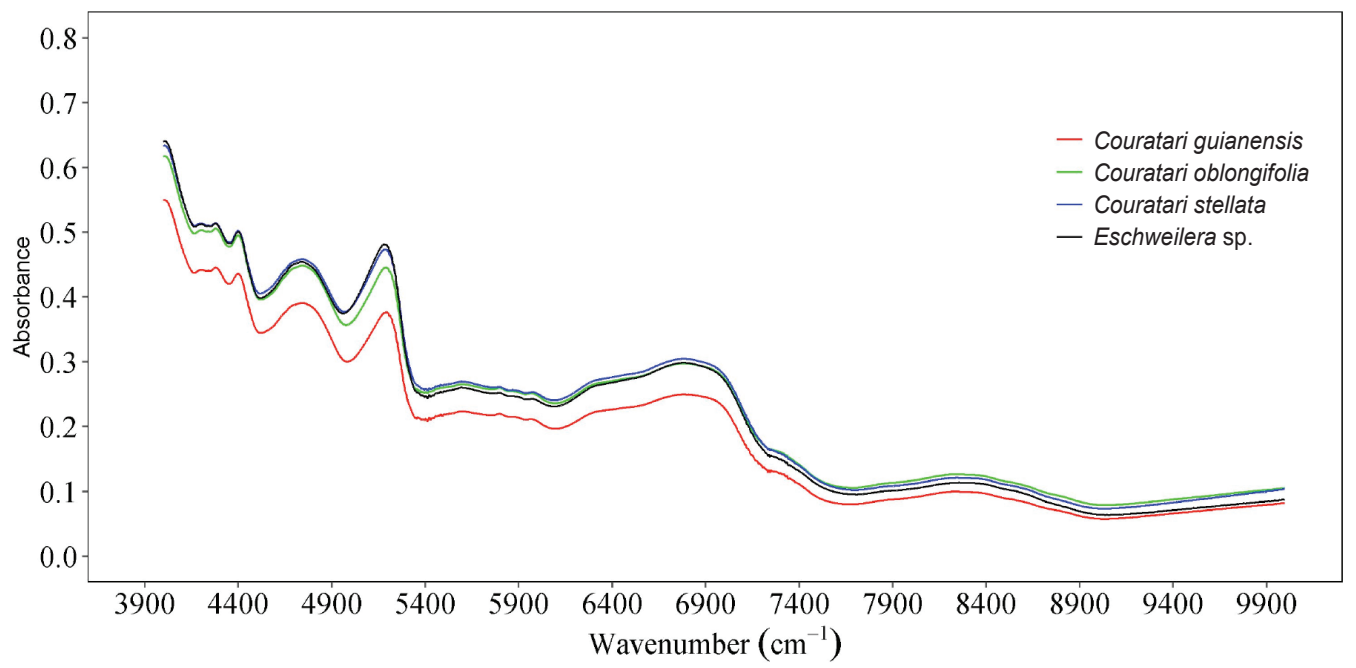

Figure 1 Mean NIR spectra of tauari species collected from different municipalities of Pará state 


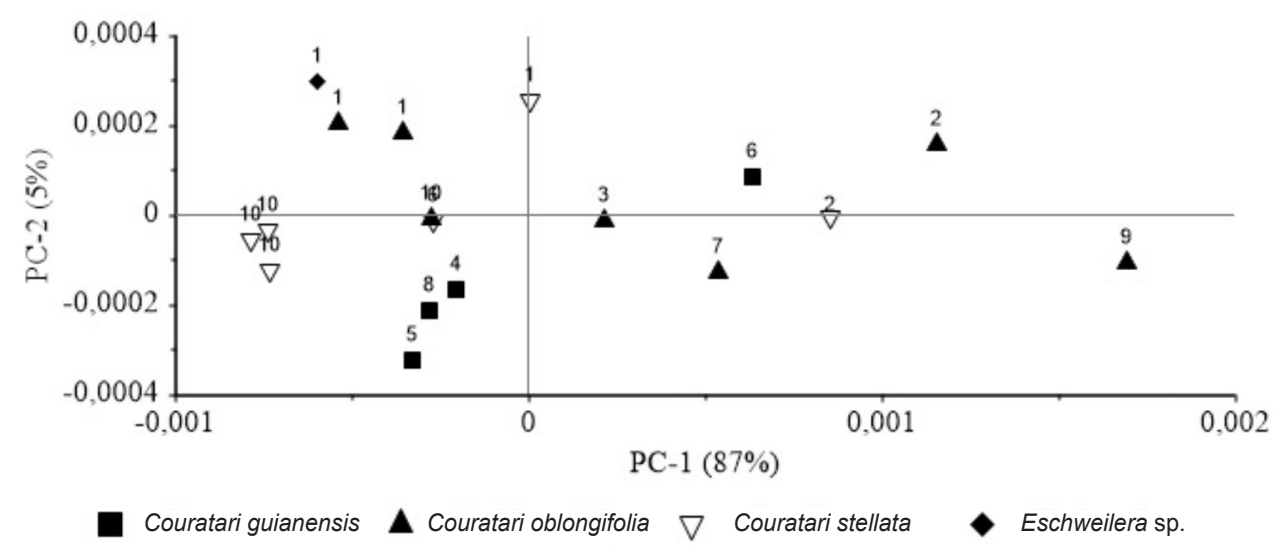

Figure 2 Score graph from principal component analysis (PCA) with mean second-derivative near-infrared (NIR) spectra of 'tauari' species collected from different municipalities of Pará state: 1 - Altamira, 2 - Anapú, 3 - Breu Branco, 4 - Goianésia, 5 - Maracajá, 6 Novo Progresso, 7 - Pacajá, 8 - Paragominas, 9 - Tailândia, 10 - Uruará

The origin of each species can influence wood quality, principally physical and mechanical properties (Gonçalez et al. 2009). Characteristics such as nutrient availability, physical properties and carbon content in soil can also influence tree growth and wood properties (Fageria 2012). The NIR spectroscopy is influenced by these factors. Sandak et al. (2011) described relations between spectra and origin of trees in Europe. Nisgoski et al. (2016) related the sensitivity of NIR in distinguishing origins of Cryptomeria japonica. Hwang et al. (2016) verified the application of the technique in pine species from different countries. Nisgoski et al. (2018a) observed the influence of toposequence position on NIR spectra of Stryphnodendron adstringens.

Evaluating the loading graph (Figure 3), it was possible to verify the regions with more influence in distinguishing 'tauari' wood species. Wavenumbers from 5974-5774 $\mathrm{cm}^{-1}$, bands at $5599 \mathrm{~cm}^{-1}$, bands at $4904 \mathrm{~cm}^{-1}$, region from $4424-4391 \mathrm{~cm}^{-1}$, wavenumber at $4366 \mathrm{~cm}^{-1}$, and region from $4349-4090 \mathrm{~cm}^{-1}$ were related to all cell wall components (cellulose, hemicelluloses and lignin). Other authors have observed variation in the use of total spectra or regions for wood identification. Pastore et al. (2011) described the wavenumbers from $4249 \mathrm{~cm}^{-1}$ to $6100 \mathrm{~cm}^{-1}$ as the most informative in separation of species similar to mahogany. Bergo et al. (2016) correctly classified samples of mahogany from 27 countries in the region from $5547 \mathrm{~cm}^{-1}$ to $6897 \mathrm{~cm}^{-1}$. Muñiz et al. (2016) indicated that regions in $4000-5000 \mathrm{~cm}^{-1}$ and $5500-6200 \mathrm{~cm}^{-1}$ are adequate for discrimination of wood species of the angelim group. Nisgoski et al. (2016) observed that bands from 4000 to $6200 \mathrm{~cm}^{-1}$ were adequate for separating six origins of sugi. Toscano et al. (2017) verified the influence of wavenumbers from 4000 to $7500 \mathrm{~cm}^{-1}$ in separation of hardwood and softwood, and pine, fir and beech. On the other hand, Hwang et al. (2016) applied spectra from 4000 to $8000 \mathrm{~cm}^{-1}$ to identify pinus species.

The influence of the surface where the spectra were obtained for tauari species collected in different municipalities of Pará state were investigated separately with transversal sections (Figure 4A) and longitudinal sections (Figure 4B). All graphs showed similar behavior, where there was no evidence of a more important section for inspection. For C. guianensis, three samples formed a group and others were more distant. For C. oblongifolia, the samples did not show a strong clustering tendency, being influenced by origin. For C. stellata, samples from the same location were grouped and other samples were distributed irregularly.

The similarity between the sections may be related to anatomical features. Muñiz et al. (2016), showed that the cross sections bring more information, mainly about vessels, parenchyma, fibers and ray cells, than longitudinal sections (radial and tangential). The influence of section in species discrimination was also evaluated by Nisgoski et al. (2018b) in Caatinga species. The authors commented that in cluster analysis, mean spectra of samples or longitudinal sections 


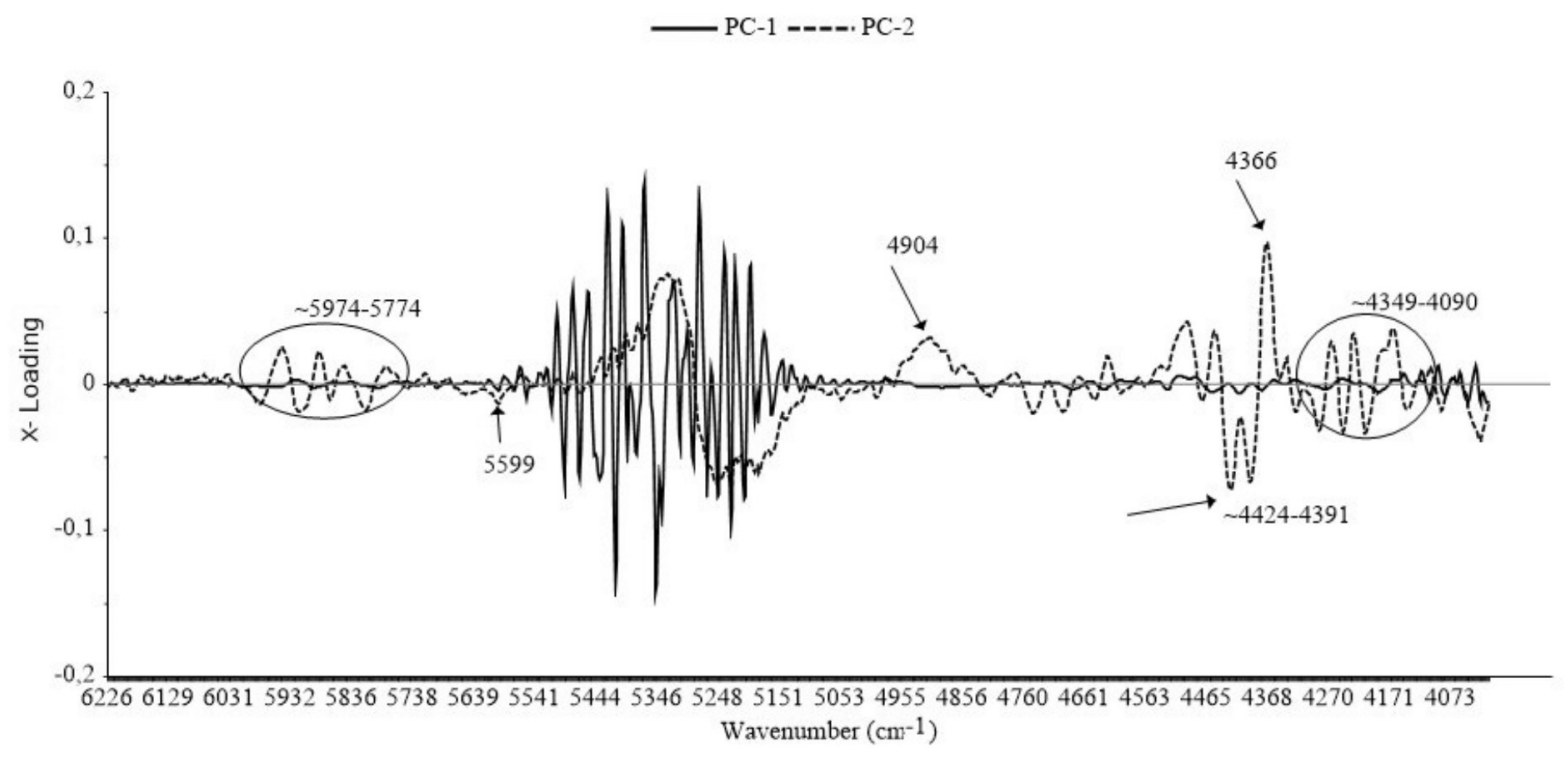

Figure 3 Factor loading graph of principal component analysis (PCA) with mean second-derivative nearinfrared (NIR) spectra from tauari species collected from different municipalities of Pará state
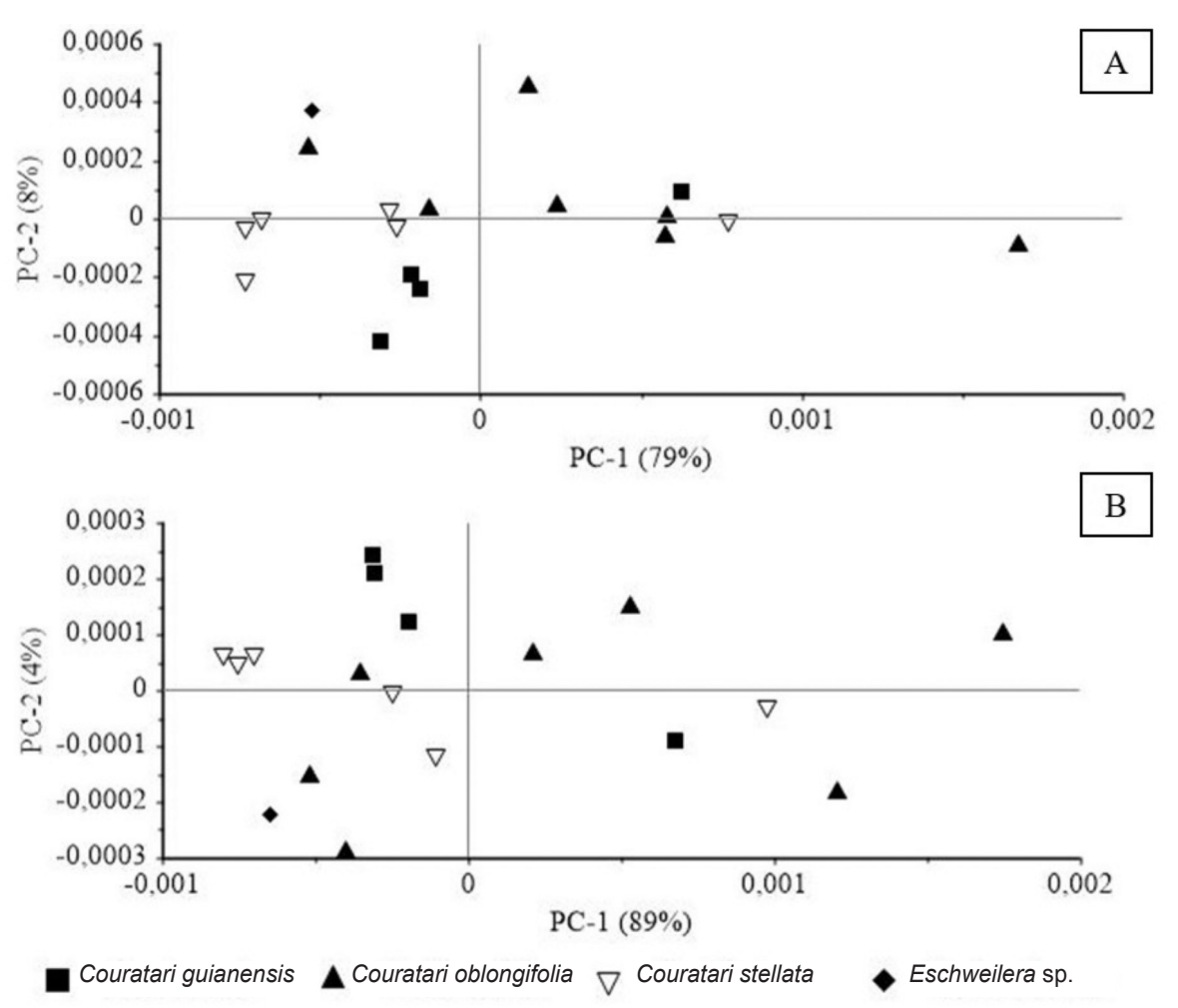

Figure 4 The principal component analysis (PCA) for second-derivative, near-infrared (NIR) spectra of tauari species collected in different municipalities of Pará state; (A) mean of transversal sections; (B) mean of longitudinal sections

were more suitable. However, for external classification, all sections showed power for species discrimination, which is important for practical applications.
The species C. guianensis, C. oblongifolia and C. stellata from the Walter A. Egler Collection and Embrapa Amazônia Oriental, and were also collected from sawmills in different regions of 
Pará state. Thus, PCA was performed to verify the grouping of species based on time of storage (Figure 5). The origin of the material had more influence, but the species remained isolated.

The analysis based on NIR spectra for monitoring wood weathering and analysis of archeological wood and chemical composition of historical wood are reported in the literature (Sandak et al. 2009, Sandak et al. 2010). Other authors have also commented that NIR spectroscopy is useful to ascertain changes in molecular degradation of wood (Inagaki et al. 2009). Thus, material can be applied for species identification independent of storage time.

Principal component analysis-linear discriminant analysis (PCA-LDA) classification of near-infrared (NIR) spectra

In model determination with NIR spectra for tauari species of samples from scientific collections, great divergence were observed between data from Walter A. Egler Collection and Embrapa Amazônia Oriental. Thus, to construct a model for external classification or identification of material obtained from different municipalities of Pará state, only spectra from Embrapa specimens were used. This was also because the samples came from regions near the sawmills.

Table 3 shows the percentage of total classification of samples collected in Pará state. Data included correct and incorrect results, showing the tendency of the model. The longitudinal surface spectra classified samples as C. multiflora, a species not identified anatomically. These results confirmed the similarity between all species of the genera Couratari. Since no sample of Eschweilera was included in constructing the model, the sample was incorrectly classified as genus Couratari.

The best results for classification of samples are shown in Table 4. It was possible to verify a difference based on pretreatment (second derivative), wavenumber (all or bands in the region $4000-7500 \mathrm{~cm}^{-1}$ ) and section where spectra were collected. These influenced species discrimination, as did intrinsic characteristics of species. In principle, PCA-LDA could provide good information for distinguishing $C$. guianensis from C. oblongifolia and C. stellata, regardless of section or wavelength.

Wood from the tauari group is similar to that of other genera of the Lecythidaceae family, and very hard to identify to the species level (Procópio \& Secco 2008). The material applied to calibrate the model was from scientific collections, submitted to varying storage times, with possible residues from preservatives, and without identification of age or position in the tree. All of these characteristics can change the chemical makeup of samples and influence NIR spectra. Even so, results indicated the technique's potential for identifying wood samples marketed as tauari.

The PCA-LDA classification has been shown to be adequate for wood identification, such as angelim and caatinga species, with variation in wavenumbers and sections with better results, indicating the predominance of individual

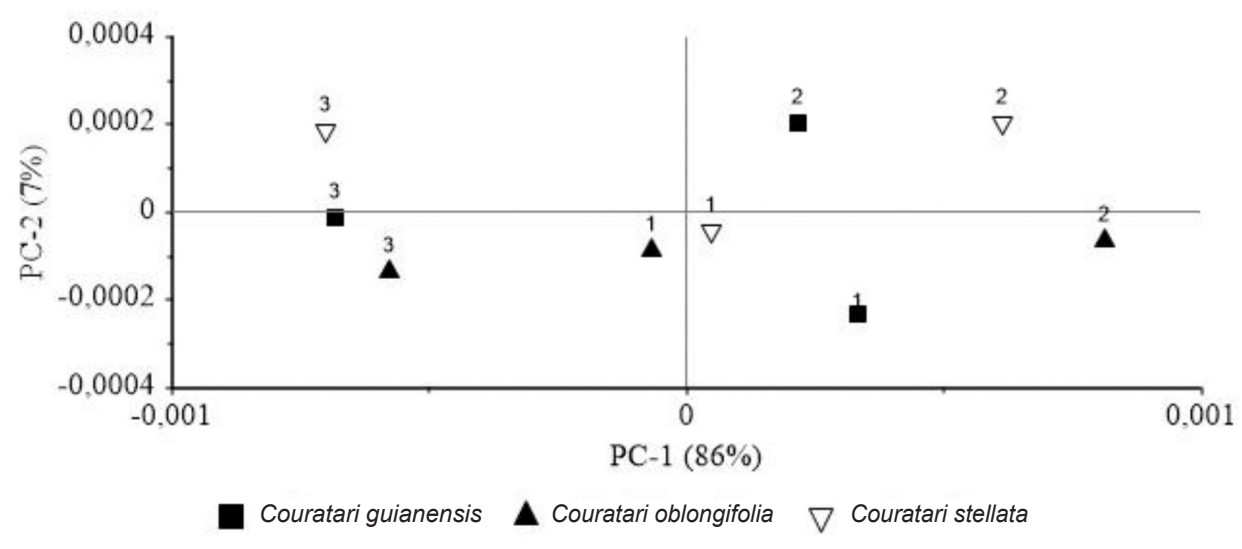

Figure 5 PCA with second-derivative spectra for species obtained from the Walter A. Egler Collection of Emilio Goeldi Museum, Embrapa Amazônia Oriental and from sawmills in different municipalities of Pará state: (1) Pará state, (2) Embrapa, (3) museum 
Table 3 Percentage of total classification of 18 samples of species collected in Pará state based on nearinfrared (NIR) model using Embrapa specimens, correct or incorrect

\begin{tabular}{|c|c|c|c|c|}
\hline NIR spectra & C. guianensis & C. multiflora & C. oblongifolia & C. stellata \\
\hline \multicolumn{5}{|l|}{ Mean of all sections } \\
\hline Raw 4000-10000 $\mathrm{cm}^{-1}$ & $11.1 \%$ & - & $33.3 \%$ & $55.5 \%$ \\
\hline $2^{\text {nd }}$ derivative $4000-10000 \mathrm{~cm}^{-1}$ & $61.1 \%$ & - & $38.9 \%$ & - \\
\hline Raw $4000-7500 \mathrm{~cm}^{-1}$ & $11.1 \%$ & - & $50.0 \%$ & $38.9 \%$ \\
\hline $2^{\text {nd }}$ derivative $4000-7500 \mathrm{~cm}^{-1}$ & $61.1 \%$ & $11.1 \%$ & $27.8 \%$ & - \\
\hline \multicolumn{5}{|l|}{ Mean of transversal section } \\
\hline Raw $4000-10000 \mathrm{~cm}^{-1}$ & $22.2 \%$ & - & $33.3 \%$ & $44.4 \%$ \\
\hline $2^{\text {nd }}$ derivative $4000-10000 \mathrm{~cm}^{-1}$ & $61.1 \%$ & - & $38.9 \%$ & - \\
\hline Raw $4000-7500 \mathrm{~cm}^{-1}$ & $55.6 \%$ & - & $50.0 \%$ & $44.4 \%$ \\
\hline $2^{\text {nd }}$ derivative $4000-7500 \mathrm{~cm}^{-1}$ & $61.1 \%$ & $11.1 \%$ & $27.8 \%$ & - \\
\hline \multicolumn{5}{|l|}{ Mean of longitudinal sections } \\
\hline Raw $4000-10000 \mathrm{~cm}^{-1}$ & $11.1 \%$ & $16.7 \%$ & $38.9 \%$ & $33.3 \%$ \\
\hline $2^{\text {nd }}$ derivative $4000-10000 \mathrm{~cm}^{-1}$ & $55.6 \%$ & - & $44.4 \%$ & - \\
\hline Raw $4000-7500 \mathrm{~cm}^{-1}$ & $11.1 \%$ & $16.7 \%$ & $50.0 \%$ & $22.2 \%$ \\
\hline $2^{\text {nd }}$ derivative $4000-7500 \mathrm{~cm}^{-1}$ & $55.6 \%$ & $11.1 \%$ & $33.3 \%$ & - \\
\hline
\end{tabular}

Table 4 Best results by species for principal component analysis-linear discriminant analysis (PCA-LDA) classification of tauari samples collected in municipalities of Pará state

\begin{tabular}{llllc}
\hline \multicolumn{1}{c}{ Species } & $\mathrm{n}$ & \multicolumn{1}{c}{ Spectra } & \multicolumn{1}{c}{ Section } & Classification \\
\hline Couratari stellata & 6 & Raw data all spectra and 4000-7500 cm & Mean of sample & $50 \%$ \\
Couratari oblongifolia & 7 & Raw data 4000-7500 cm-1 & Longitudinal sections & $57 \%$ \\
Couratari guianensis & 4 & 2nd derivative $4000-7500 \mathrm{~cm}^{-1}$ & All sections & $100 \%$ \\
\hline
\end{tabular}

characteristics in spectra obtained from solid material (Muñiz et al. 2016, Nisgoski et al. 2018b).

For native species, a database reflecting the most prevalent variations in samples' characteristics is necessary, such as age, origin and position in tree. This is the first study using NIR spectroscopy on wood marketed as tauari, and the exploratory results showed the possibility of application in practice. However, analysis of more species of the $C$. genus and Lecythidaceae family is recommended.

\section{CONCLUSION}

The NIR spectroscopy, based on principal component analysis of second-derivative spectra showed promising results for characterisation and identification of species from the tauari group. The PCA-LDA, with data in the region of
$4000-7500 \mathrm{~cm}^{-1}$, provided the best information for species distinction. However, further research is necessary to build a database with maximum diversity of species from the $C$. genus and others genera and species of the Lecythidaceae family that are similar, using samples grown in other edaphoclimatic conditions and from different axial and radial positions of the trees.

\section{REFERENCES}

Bergo MCJ, Pastore tCM, Coradin VTR, Wiedenhoeft AC \& BRAGA JWB. 2016. NIRS identification of Swietenia macrophylla is robust across specimens from 27 countries. Iawa Journal 37: 420-430.

Bernal Ra, Coradin V, Camargos JaA, Costa C \& Pissarra J. 2011. Wood anatomy of Lecythidaceae species called tauari. Iawa Journal 32: 1-17.

Coradin VTR, Camargos JAA, Pastore TCM \& Christo AG. 2011. Madeiras Comerciais do Brasil: Chave Interativa de Identificação Baseada em Caracteres 
Gerais e Macroscópicos. Serviço Florestal Brasileiro, Laboratório de Produtos Florestais, Brasília.

FAGERIA NK. 2012. Role of soil organic matter in maintaining sustainability of cropping systems. Communications in Soil Science and Plant Analysis 43: 2063-2113.

Forzza RC, Baumgratz JFA, Bicudo CEM et al. 2012. New brazilian floristic list highlights conservation challenges. Bioscience 62: 39-45.

Gonçalez JC, Vieira FS, Camargos JAA \& Zerbini NJ. 2009. Influence of the site on the properties of Pinus caribeae var. hondurensis wood. Cerne 15: 251-255.

Horikawa Y, Tazuru SM \& Sugiyama J. 2015. Near-infrared spectroscopy as a potential method for identification of anatomically similar Japanese diploxylons. Journal of Wood Science 61: 251-261.

Hwang SW, Horikawa WH, Lee WH \& Sugiyama J. 2016. Identification of pinus species related to historic architecture in Korea using NIR chemometric approaches. Journal of Wood Science 62: 156-167.

IAWA (International Association of Wood Anatomists). 1989. List of microscopic features of hardwood identification. Netherlands. IAWA Bulletin 10: 221-332.

Inagaki T, Mitsui K \& Tsuchikawa S. 2009. Near-infrared spectroscopic investigation of the hydrothermal degradation mechanism of wood as an analogue of archaeological wood. Part II: hardwood. Applied Spectroscopy 63: 753-758.

ITTO (Internacional Tropical Timber Organization). 2005. Utilization of Lesser Utilized Timber Species of Guyana. Guyana Forestry Commission. ITTO, Yokohama.

Li Y, Via BK, Cheng Q, Zhao J \& Li Y. 2019. New pretreatment methods for Vis-NIR calibration modeling of air-dry density of Ulmus pumila wood. Forest Products Journal 69: 195-204.

Magalhães Wle, Pereira JCD, Muñiz Gib, Klock U \& SILVA JRM. 2005. Determination of chemical and anatomical properties of wood with the use of diffuse near infrared reflection. Boletim de Pesquisa Florestal 50: 25-36.

Martins SRCV, Michael GH \& Ian ST. 2003 Botanical identification in the Amazon: current situation and perspectives. Embrapa Amazônia Oriental 4: 1-77.

Muñiz GIB, Carneiro ME, Batista FRR, Schardosin FZ \& NISGOSKI S. 2016. Wood and charcoal identification of five species from the miscellaneous group known in brazil as 'angelim' by near-infrared and wood anatomy. Maderas. Ciencia y Tecnología 18: 505-522.

Nisgoski S, Batista FRR, Naide TL, Laube NCC, Leão ACR \& MuÑIz GIB. 2018B. Discrimination of wood and charcoal from six Caatinga species by near-infrared spectroscopy. Maderas. Ciencia y Tecnología 20: 199-210.

Nisgoski S, Gonçalves TAP, Oliveira NM, Bittencourt SC, Lima GS \& MuÑiz GIB. 2018A. Influence of toposequence position of Stryphnodendron adstringens trees on discrimination of samples based on spectroscopy. Ciência da Madeira 9: 112-122.

Nisgoski S, Schardosin FZ, Batista FRR, Muñiz GiB \& Carneiro ME. 2016. Potential use of NIR spectroscopy to identify Cryptomeria japonica varieties from southern brazil. Wood Science and Technology 50: 71-80.
PASQUINI C. 2003. Near infrared spectroscopy: fundamentals, practical aspects and analytical applications. Journal of the Brazilian chemical society 14: 198-219.

Pastore TC, Braga JWB, Coradin VTR et al. 2011. Near infrared spectroscopy (NIRS) as a potential tool for monitoring trade of similar woods: discrimination of true mahogany, cedar, andiroba, and curupixa. Holzforschung 65: 73-80.

Paula JE \& Costa KP. 2011. Wood Density of 932 Native Species From Brazil. Cinco Continentes Editora, Porto Alegre.

Procópio LC \& Secco RS. 2008. The importance of botanical identification in forest inventories: the example of tauari (Couratari spp. and Cariniana spp. - Lecythidaceae) in two areas managed in the state of Pará. Acta Amazonica 38: 31-44.

Rinnan A, Van Den Berg F \& Engelsen SB. 2009. Review of the most common pre-processing techniques for near-infrared spectra. Trac Trends in Analytical Chemistry 28: 1201-1222.

Sandak A, Sandak J, Prądzyński W, Zborowska M \& Negri M. 2009. Near infrared spectroscopy as a tool for characterization of wood surface. Folia Forestalia Polonica 40: 31-40.

Sandak A, Sandak J, Zborowska M \& Pradzynski W. 2010. Near infrared spectroscopy as a tool for archaeological wood characterization. Journal of Archaeological Science 37: 2093-2101.

Sandak A, SANdak J \& Negri M. 2011. Relationship between near-infrared (NIR) spectra and the geographical origin of timber. Wood Science and Technology 45: $35-48$.

SCHWANNInger M, Rodrigues JC \& FACKLER K. 2011. A review of band assignments in near infrared spectra of wood and wood components. Journal of Near Infrared Spectroscopy 19: 287-308.

SFB (Serviço Florestal Brasileiro). 2013. Forests of Brazil In Short-2013: Data from 2007-2012. SFB, Brasília.

Soares LF, Silva DC, Bergo MCJ, Coradin VTR, Braga JWB \& Pastore TCM. 2017. Evaluation of portable NIR and pls-da spectrometer for the discrimination of six similar amazonian wood species. Química Nova 40: 418-426.

Souza AMD \& Poppi RJ. 2012. Experimento didático de quimiometria para análise exploratória de óleos vegetais comestíveis por espectroscopia no infravermelho médio e análise de componentes principais: um tutorial. Parte I. Química Nova 35: 223-229.

Souza VC \& Lorenzi H. 2005. Illustrative Guide to Identify the Families of Angiosperms of Brazilian Flora APG II. Instituto Plantarum, São Paulo.

Toscano G, Rinnan A, Pizzi A \& Mancini M. 2017. The use of near-infrared (NIR) spectroscopy and principal component analysis (PCA) to discriminate bark and wood of the most common species of the pellet sector. Energy Fuels 31: 2814-2821.

Tsuchikawa S. 2007. A review of recent near infrared research for wood and paper. Applied Spectroscopy Reviews 42: 43-71.

Tsuchikawa S \& Kobori H. 2015. A review of recent application of near infrared spectroscopy to wood science and technology. Journal of Wood Science 61: 213-220. 
Yang JL \& Evans R. 2003. Prediction of MOE of Eucalyptus wood from microfibril angle and density. Holz Als Roh-Und Werkstoff 61: 449-452.
Zhang X, Yu H, Li B, Li WJ, Li X \& Bao C. 2014. Discrimination of Pinus yunnanensis, $P$. kesiya and $P$. densata by ft-NIR. Journal of Chemical and Pharmaceutical Research 6: 142-149. 